\title{
ASSESSMENT OF ECO-EFFICIENCY OF SEPARATION OF SOME FRACTIONS OF MSW: A CASE STUDY OF GEORGIA, SOUTH CAUCASUS
}

\author{
NATELA L. DVALISHVILI \\ Department of Environmental Pollution Monitoring and Prognosis of Institute of Hydrometeorology \\ at Georgian Technical University, Georgia
}

\begin{abstract}
Socio-economic development in Georgia is interconnected with the amount of municipal solid waste; in accordance with the statistical information of 2010-2017 it is $1.7 \%$ per year. The law on "Waste Management Code" was approved on January 15 2015, which regulates the waste management policy in Georgia, including separation activities and requirenments. During the last few years the first steps have been made towards the improvement of waste collection, disposal and landfill operations by municipality government, however the issue of waste minimization and decontamination still remains the challenge for the country. Based on the experimental databases of the morphological composition of MSW, which has been studied in 2015-2017, we estimated the amount of secondary use of some fractions of MSW, their impact on climate change and potential options for mitigating climate change. According to the data processing, and as a result of measures implemented in accordance with the national index of separation of MSW, $25 \%$ of whole MSW will be presented as a secondary raw material in 2030. Minimization of some fraction of MSW will cause reduction of methane emissions from SWDS of Georgia in 2020-2030, an average of 4.1\%.

Keywords: waste management, municipal solid waste, separation, composition, greenhouse gases, inventory.
\end{abstract}

\section{INTRODUCTION}

The improvement of solid waste management in Georgia implying harmonization of the ongoing process of the development of waste management system in Georgia with the European waste management policy is one of the state priorities. $98 \%$ of solid wastes, which are generated in Georgia, gather at the landfills (managed or illegal) without any processing [1]. Depending on the specifics of the generated waste in the country (Table 1) the mixed waste placed on landfills, due to decomposing - emit landfill gases in a large amount - which are not extracted at any landfill of Georgia [8]. Waste landfilling leads to the contamination of the environmental components (soil, water, air), which in turn affects human health. Along with the world population growth and improvement of living standards, the amount of generated waste increases.

There are only two officially managed landfills in Georgia with installed landfill gas pipelines (collectors), but there is no infrastructure for burning or utilization of methane from the gas collectors, so these gases are emitted to atmospheric air without any cleaning/ processing. The only purpose of the gas pipes is to remove them directly from the landfill surface, which cannot solve the problem in terms of environmental impacts [9], [10].

Based on the dynamic of waste generation observed in 2010-2017, the rate of growth of waste volumes is $1.7 \%$ a year [1]. Developed countries are actively working on the development of waste minimization and safe and cost-efficient waste disposal techniques. Waste minimization is closely linked to sustainable economic development of the country. Waste recycling or the process of converting waste materials into new materials is one of the main elements of modern waste management technologies. Most of household, agricultural and other wastes generated in the country are recyclable. 
Table 1: Morphological composition of MSW in Georgia, (wt. \%) (2015-2017) [5].

\begin{tabular}{|c|l|c|c|c|c|c|c|c|c|c|c|c|}
\hline$\#$ & Region & Glass & Paper & Metal & Plastic & Hygienic & $\begin{array}{c}\text { Rubber/ } \\
\text { Textile }\end{array}$ & $\begin{array}{c}\text { Wood } \\
\text { Garden }\end{array}$ & $\begin{array}{c}\text { Fine } \\
\text { Fraction }\end{array}$ & Hazard & Food & Total \\
\hline 1 & 2 & 3 & 4 & 5 & 6 & 7 & 8 & 9 & 10 & 11 & 12 & 13 \\
\hline 1 & Tbilisi & 3.5 & 13.2 & 1.7 & 15.2 & 8.1 & 2.2 & 0.7 & 3.7 & 0.8 & 51.1 & 100 \\
\hline 2 & $\begin{array}{l}\text { Samtskhe- } \\
\text { Javakheti }\end{array}$ & 2.8 & 12.0 & 3.2 & 13.8 & 6.8 & 0.8 & 0.8 & 10.8 & 0.4 & 48.6 & 100 \\
\hline 3 & Kakheti & 2.8 & 11.2 & 2.9 & 11.5 & 5.0 & 1.0 & 0.3 & 22.6 & 0.5 & 42.2 & 100 \\
\hline 4 & Shida Kartli & 3.1 & 11.3 & 2.8 & 15.6 & 5.2 & 0.5 & 0.7 & 16.7 & 0.3 & 43.8 & 100 \\
\hline 5 & Adjara & 2.8 & 15.5 & 2.5 & 15.4 & 7.2 & 1.7 & 0.2 & 9.8 & 0.8 & 44.1 & 100 \\
\hline 6 & Guria & 2.2 & 11.6 & 3.5 & 15.5 & 5.7 & 0.4 & 0.5 & 17.7 & 0.8 & 42.1 & 100 \\
\hline 7 & $\begin{array}{l}\text { Mtskheta- } \\
\text { Mtianeti }\end{array}$ & 1.5 & 9.9 & 3.8 & 15.5 & 5.9 & 1.8 & 0.7 & 16.0 & 1.0 & 43.9 & 100 \\
\hline 8 & $\begin{array}{l}\text { Samegrelo- } \\
\text { Zemo } \\
\text { Svaneti }\end{array}$ & 2.6 & 9.9 & 1.9 & 12.1 & 7.0 & 1.2 & 1.5 & 19.5 & 0.8 & 43.5 & 100 \\
\hline 9 & $\begin{array}{l}\text { Racha- } \\
\text { Lechkhumi }\end{array}$ & 2.4 & 13.5 & 1.5 & 13.2 & 9.0 & 1.3 & 0.2 & 16.5 & 0.5 & 41.9 & 100 \\
\hline 10 & $\begin{array}{l}\text { Kvemo } \\
\text { Kartli }\end{array}$ & 0.7 & 11.3 & 3.0 & 13.8 & 7.9 & 1.6 & 0.4 & 19.2 & 1.4 & 39.6 & 100 \\
\hline 11 & Imereti & 1.5 & 11.2 & 2.5 & 14.3 & 6.7 & 1.4 & 0.1 & 16.2 & 1.0 & 45.1 & 100 \\
\hline 12 & Average & 2.4 & 11.9 & 2.7 & 14.2 & 6.8 & 1.3 & 0.6 & 15.3 & 0.8 & 44.1 & 100 \\
\hline
\end{tabular}

${ }^{1}$ The MSW almost does not contain wood fraction, because of wood waste is burned by the population.

\section{THE LEGAL FRAMEWORK OF WASTE MANAGEMENT OF GEORGIA}

The Government of Georgia has been actively working to address the above issue. The first legislative act, which defines the waste management policy, including reuse of waste has been approved in January 2015 [2]. Municipal services have made first steps towards the improvement of waste collection, disposal and landfill operations; however, the issue of waste minimization and decontamination still remains the challenge, which need to be addressed. There are several methods of waste minimization/decontamination, including solid municipal waste separation, which is one of the most effective methods. The use of the above method of waste minimization/decontamination largely relies on the quantity and characteristics of waste and selection of the best available technology. The MSW separation requirenments are determined by the Resolution of the Government \#160 2016-2030 National Waste Management Strategy and and its 2016-2020 Action Plan [3]. The separation method is the best way to reduce the amount of landfilled, which will make easier to reuse the waste that care hardly reused or recycled.

\subsection{Action plan and strategy of waste management}

Currently, separation of MSW is not carried out in Georgia, mixed waste are accumulating on the solid waste disposal site (SWDS), solely a few places of the big cities of the country are locating some urns for 3-4 fraction of waste (paper, glass, plastic, metal), but the national waste management strategy requires the removal of the four main fractions of MSW from 2020 (Table 2), which will lead to a change in the emission of greenhouse gases from SWDS.

Presently disposal rates on official landfills in Georgia are about $48 \%$ of whole generated MSW. Up to $52 \%$ of mixed wastes generated on the territory of Georgia are arbitrarily disposed on the areas adjacent to settlements - river channels, riverbanks and even on pasturelands, which lead to a sharp deterioration in the ecological state of these areas [1], [4], [5]. According to the national waste management strategy (from 2020) the disposal rates on 
Table 2: National index of separation of municipal solid waste [3].

\begin{tabular}{|l|c|c|c|}
\hline Fraction of MSW & 2020 & 2025 & 2030 \\
\hline Paper & $30 \%$ & $50 \%$ & $80 \%$ \\
\hline Glass & $20 \%$ & $50 \%$ & $80 \%$ \\
\hline Metal & $70 \%$ & $80 \%$ & $90 \%$ \\
\hline Plastic & $30 \%$ & $50 \%$ & $80 \%$ \\
\hline
\end{tabular}

official landfills in Georgia will grow: 2020 - 90\%, $2025-100 \%$ and $2030-100 \%$ (National Index of Collection of Municipal Solid Waste) [3]. Farthermore the strategy framework includes arrangement of the biogas collection/recycling system, but only at two landfills of the country, in particular, burning the biogas (plan of Tbilisi City Hall and Waste Management Company before the 2020).

\section{RESEARCH AIMS, OBJECTIVES AND METHODOLOGY}

The aim of the research was to assess the impact of MSW generated in Georgia on climate change after the separation process. The use of the above-mentioned method of waste minimization largely relies on the quantity and characteristics of waste.

The objectives of the research included: to assess the potential of separation of MSW, to evaluate and prognosis the impact of possible separation of MSW on climate change. This type of scientific research has never been carried out in Georgia and will path the way for the implementation of 2016-2030 National Waste Management Strategy and 2016-2020 Action Plan, which faces the serious challenges.

The framework of research was a comprehensive assessment of the potential of separation of MSW in Georgia based on the project "Elaboration of Methodology for Determination of Accumulated Amount and Morphological Composition of MSW in Georgia and Database Creation" (FR/88/9-220/14) funded by the Shota Rustaveli National Science Foundation [1], inline with activities specified in 2016-2030 National Waste Management Strategy and 2016-2020 Action Plan [3]. The research methodology considers:

- Systematization of the data on amounts and composition of MSW by the regions of Georgia;

- Collection and systematization of the statistical data (size of population, number of plants, etc.) by the regions of Georgia;

- Assessment on the impact of separation of MSW on climate changes in all regions of Georgia till 2030, using IPCC-2006 methodology [6];

- Evaluation of potential of second raw materials in case of the introduction of MSW separation practice in Georgia.

\section{THE DATA USAGE}

MSW separation measures will not only minimize and reuse of MSW, but also reduce the negative impact on the environment and climate change.

To assess the impact of MSW separation on climate change, we investigated the quantity and morphological composition of the MSW in all regions of Georgia, it also includes interview with population of this regions and gravimetric analysis [5].

The survey revealed that the average of $250 \mathrm{~kg} / \mathrm{cap} / \mathrm{year}$ of MSW are generated in Georgia, while the annual growth in the amount of MSW is $1.7 \%$, at the same time the main fraction of MSW is the organic fraction (Table 1). 


\section{RESULT OF RESEARCH}

Based on received data of MSW were calculated reducing amount of mixed waste (Table 3) and GHG emissions from the waste sector from 2018 to 2030 using the 2006 IPCC methodology (Table 4) [6], in condition of the population for 2018 (average - 3,728,000 people) [7], national index of collection of MSW [3], national index of separation of MSW [3], taking into account the fact that landfills will anaerobic management (controlled placement of waste (i.e., Waste directed to specific deposition areas, a degree of control of scavenging and a degree of control of fires) and include; mechanical compacting; levelling of the waste) and the default values of the IPCC methodology [6].

Table 3: Forecast of reduce mixed MSW under conditions performance of separation of MSW.

\begin{tabular}{|c|c|c|c|c|c|c|c|}
\hline \multirow{2}{*}{ Year } & \multicolumn{5}{|c|}{ Amount of separated waste, $\mathrm{t}$} & \multirow{2}{*}{$\begin{array}{c}\text { Mixed } \\
\text { waste, } \mathrm{t}\end{array}$} & $\begin{array}{c}\text { Waste } \\
\text { reduce, } \%\end{array}$ \\
\cline { 2 - 5 } & Glass & Paper & Metal & Plastic & Sum & & 10.2 \\
\hline 2020 & 4.7 & 35.0 & 18.5 & 41.8 & 100.0 & 980.3 & 11.4 \\
\hline 2021 & 6.2 & 40.3 & 19.4 & 48.1 & 114.1 & 997.0 & 12.7 \\
\hline 2022 & 7.8 & 45.9 & 20.3 & 54.7 & 128.6 & $1,014.0$ & 13.9 \\
\hline 2023 & 9.4 & 51.5 & 21.2 & 61.5 & 143.6 & $1,031.2$ & 15.2 \\
\hline 2024 & 11.1 & 57.4 & 22.1 & 68.5 & 159.1 & $1,048.7$ & 16.4 \\
\hline 2025 & 12.8 & 63.5 & 23.0 & 75.7 & 175.0 & $1,066.6$ & 18.2 \\
\hline 2026 & 14.6 & 72.3 & 24.0 & 86.3 & 197.1 & $1,084.7$ & 19.9 \\
\hline 2027 & 16.4 & 81.4 & 25.0 & 97.1 & 219.9 & $1,103.1$ & 21.7 \\
\hline 2028 & 18.3 & 90.8 & 26.1 & 108.3 & 243.5 & $1,121.9$ & 23.5 \\
\hline 2029 & 20.3 & 100.5 & 27.1 & 119.9 & 267.7 & $1,141.0$ & 23.5 \\
\hline 2030 & 22.3 & 110.5 & 28.2 & 131.8 & 292.8 & $1,160.3$ & 25.2 \\
\hline
\end{tabular}

Table 4: Forecast of GHG emission from waste sector for current conditions and under conditions performance of separation of MSW.

\begin{tabular}{|c|c|c|c|}
\hline \multirow{2}{*}{ Year } & \multicolumn{2}{|c|}{ GHG $\left(\mathrm{Gg} \mathrm{CH}_{4}\right.$ in $\mathrm{CO}_{2}$ eq $)$} & \multirow{2}{*}{ Reduce, $\%$} \\
\cline { 2 - 3 } & Basic & Separation & \\
\hline 2018 & $1,036.1$ & $1,036.1$ & 0.0 \\
\hline 2019 & $1,061.9$ & $1,061.9$ & 0.0 \\
\hline 2020 & $1,085.7$ & $1,084.9$ & 0.1 \\
\hline 2021 & $1,119.5$ & $1,111.6$ & 0.7 \\
\hline 2022 & $1,156.2$ & $1,139.8$ & 1.4 \\
\hline 2023 & $1,177.9$ & $1,152.1$ & 2.2 \\
\hline 2024 & $1,212.9$ & $1,176.8$ & 3.0 \\
\hline 2025 & $1,248.8$ & $1,201.2$ & 3.8 \\
\hline 2026 & $1,286.08$ & $1,225.66$ & 4.7 \\
\hline 2027 & $1,321.97$ & $1,247.18$ & 5.7 \\
\hline 2028 & $1,355.96$ & $1,265.58$ & 6.7 \\
\hline 2029 & $1,390.07$ & $1,282.11$ & 7.8 \\
\hline 2030 & $1,422.89$ & $1,296.28$ & 8.9 \\
\hline Average (2020-2030) & & 4.1 \\
\hline
\end{tabular}




\section{CONCLUSIONS}

Table 4 shows that if no measures would be carried out, GHG emissions will increase by $37 \%$ in 2030 , to compare to 2018 . If all of the measures will be carried out, then:

- Separation of some fractions of MSW from 2020 (paper - 30\% (2020), 50\% (2025), 80\% (2030); glass - 20\% (2020), 50\% (2025), 80\% (2030); metal - 70\% (2020), 80\% (2025), $90 \%$ (2030); plastic - 30\% (2020), 50\% (2025), 80\% (2030)). The mixed waste amount by 2030 will be reduced $25 \%$ (Table 3 );

- If the sepatation activities is started in 2020, during 2020-2030, Georgia's GHG emissions will decrease $-4.1 \%$ average, while in 2030 the GHG reduction will reach $8.9 \%$ compared to 2018 (Table 4 ).

Implementation of the measures of separation will contribute to significant reduction of GHG emission from landfills of Georgia, to decrease waste amount and landfills area, which in turn will contribute to the harmonization of current waste management practices with the EU standards and improve environmental and economic conditions of the country.

Based on National Morphological composition of MSW (Table 1), besides the separation and reuse of the above-mentioned fractions, separation and then composting or anaerobic digestion of food fraction of waste will give more tangible results both economically and environmentally [11].

\section{ACKNOWLEDGEMENT}

Funded by Shota Rustaveli National Science Foundation of Georgia.

\section{REFERENCES}

[1] Dvalishvili, N.L., Project of SRNSF "Elaboration of Methodology for Determination of Accumulated Amount and Morphological Composition of Municipal Solid Waste in Georgia and Database Creation" (geo). http://ecohydmet.ge/narchenebi.html.

[2] Waste Management Code, https://matsne.gov.ge/en/document/view/2676416.

[3] The National Waste Management Strategy for 2016-2020, The National Waste Management Action Plan for 2016-2020, \#160, Government of Georgia, (geo). https://matsne.gov.ge/ka/document/view/3242506.

[4] Performance Audit of Municipal Solid Waste Management, https://sao.ge/files/auditi/ efeqtianobis-angarishi/Solid-Waste.pdf.

[5] Dvalishvili, N.L. \& Tabatadze, M.S., The influence of municipal solid waste of Georgia on climate changes. Waste management and resource efficiency. Proceedings of 6th Icon SWM. www.springer.com/us/book/9789811072895, 2016.

[6] 2006 IPCC Guidelines for National Greenhouse Gas Inventories. www.ipcc-nggip.iges.or.jp/public/2006gl/vol5.html.

[7] Mid-Year Population by Self-Governed Units (Thousand Persons). http://geostat.ge/index.php?action=page\&p_id=473\&lang=eng.

[8] Sustainable Energy Action Plan (SEAP). http://remissia.ge/en/publications/seap.

[9] http://waste.gov.ge/ka/?page_id=1027\&lang=en.

[10] Dvalishvili, N.L., Establishment of energy potential of Norio landfill of municipal solid waste of Tbilisi. Procedia Environmental Sciences, 35, pp. 377-380, 2016. www.sciencedirect.com/science/article/pii/S1878029616301062.

[11] Dvalishvili, N. \& Tsintsadze, T., Impact of biological treatment of municipal solid waste on climate change in Georgia. 7th International Conference on Solid Waste Management, Hyderabad, India, 15-17 Dec. 2017. 